\title{
Pembuatan Rice Crackers dengan Penambahan Beras Merah (Oryza nivara) dan Serbuk Daun Kelor (Moringa oleifera) sebagai Pangan Fungsional
}

\section{Making Rice Crackers With Addition To Red Rice (Oryza nivara) And A Powder Of Kelor Leaves (Moringa oleifera) As A Functional Food}

\author{
Fais Bintang Malibun, Program Studi Pendidikan Teknologi Pertanian Fakultas Teknik, \\ Universitas Negeri Makassar. Email: Fais.bintang2017@gmail.com \\ Husain Syam, Program Studi Pendidikan Teknologi Pertanian Fakultas Teknik, Universitas \\ Negeri Makassar. Email: husain6677@yahoo.co.id \\ Andi Sukainah, Program Studi Pendidikan Teknologi Pertanian Fakultas Teknik, Universitas \\ Negeri Makassar. Email: andisukainah@yahoo.com
}

\begin{abstract}
Abstrak
Pembuatan rice crackers dengan penambahan tepung beras merah dan serbuk daun kelor diharapkan mampu menambah kualitas yang ada pada pangan tersebut sehingga dapat menjadi produk pangan fungsional. Penelitian ini bertujuan untuk mengetahui pengaruh penambahan tepung beras merah dan serbuk daun kelor terhadap kualitas rice crackers. Metode yang digunakan adalah penelitian kuantitatif dengan pendekatan eksperimen. Penelitian ini menggunakan rancangan acak lengkap (RAL) dengan 5 perlakuan yang terdiri dari perbandingan tepung beras merah dan serbuk daun kelor yaitu kontrol, 50:0 \%, 48:2 \%, 47,5:2,5 \%, dan 47:3 \% dengan 3 kali ulangan. Penelitian ini dilakukan melalui dua tahap. Tahap pertama adalah pembuatan tepung beras merah dan serbuk daun kelor. Tahap kedua adalah pembuatan rice crackers. Variabel yang diamati adalah analisis kadar proksimat (kadar air, protein, karbohidrat, lemak, dan serat kasar), fosfor, dan uji organoleptik. Data diolah menggunakan program SPSS versi 21, dengan metode analisis of varians (ANOVA) dan dilanjutkan dengan tes DMRT (Duncan). Hasil penelitian menunjukkan bahwa penambahan tepung beras merah dan serbuk daun kelor memberikan pengaruh terhadap rice crackers yang dihasilkan. Hasil uji organoleptik rice crackers secara keseluruhan diterima oleh konsumen terutama perlakuan dengan perbandingan $48 \%$ tepung beras merah dan $2 \%$ serbuk daun kelor sebagai perlakuan terbaik dengan kadar air $2,42 \%$, protein $6,77 \%$, karbohidrat $84,58 \%$, lemak $3,34 \%$, serat kasar $1,52 \%$, dan fosfor $0,20 \%$.
\end{abstract}

Kata Kunci: Tepung beras merah, serbuk daun kelor, rice crackers

\section{Abstract}

Making rice crackers by adding red rice flour and moring a leaf powder is expected to increase the quality of the food so that it can become a functional food product.This study aims to determine the effect of adding brown rice flour and moring a leaf powder to the quality of rice crackers. This research is a quantitative research with an experimental approach. This study used a completely randomized design (CRD) with 5 treatments consisting of a comparison of brown rice flour and moringa leaf powder, namely control, 50: 0\%, 48: 2\%, 47.5: 2.5\%, and 47: $3 \%$ with 3 replications. This research was conducted in two stages. The first stage is the manufacture of brown rice flour and moringa leaf powder. The second stage is making rice crackers. The variables observed were the analysis of proximate levels (water content, protein, carbohydrate, fat, and crude fiber), phosphorus, and organoleptic tests. The data was processed using the SPSS version 21 program, with an analysis of variance (ANOVA) method and continued with the DMRT test (Duncan). The results showed that the addition of red rice flour and moringa leaf powder had an influence on the rice crackers produced. The overall organoleptic rice crackers test was accepted by consumers, especially the treatment with a 
ratio of $48 \%$ brown rice flour and $2 \%$ moringa leaf powder as the best treatment with water content of $2.42 \%$, protein $6.77 \%$, carbohydrates $84.58 \%$, fat 3,34\%, $1.52 \%$ crude fiber, and $0.20 \%$ phosphorus.

Keywords: Brown rice flour, moringa leaf powder, rice crackers

\section{Latar Belakang}

Rice crackers adalah salah satu makanan tradisional dari Jepang yang terbuat dari tepung beras atau beras ketan yang memiliki tekstur renyah, rasa asin dan gurih. Pada proses pembuatan rice crackers juga mengalami proses pengembangan volume dan membentuk tekstur yang berpori dikarenakan terjadinya proses gelatinisasi pati pada beras tersebut (Mariana, 2010).

Menurut Badan Standarisasi Nasional (2011), crackers termasuk salah satu jenis biskuit selain biskuit keras, cookies, wafer, dan pai. Salah satu jenis rice crackers yang ada di Indonesia adalah opak. Namun, rice crackers atau opak yang ada saat ini masih kurang diminati oleh masyarakat dikarenakan memiliki kualitas yang rendah seperti rasa dan kandungan gizi dibandingkan dengan produk rice crackers atau produk biskuit lainnya (Mariana, 2010). Kualitas rice crackers dapat ditingkatkan dengan cara menambahkan bahan yang memiliki kandungan gizi yang tinggi seperti beras merah dan daun kelor.

Beras merah (Oryza nivara) adalah salah satu jenis beras selain beras putih, beras hitam dan beras ketan, yang memiliki warna merah disebabkan oleh senyawa antosianin. Beras merah umumnya hanya dikonsumsi tanpa melalui proses penyosohan tetapi hanya digiling menjadi beras pecah kulit. Beras merah memiliki kandungan gizi per 100 gram berupa protein 7,5 g, lemak 0,9 g, karbohidrat 77,6 $\mathrm{g}$, kalsium $16 \mathrm{mg}$, fosfor $160 \mathrm{mg}$, zat besi $0,3 \mathrm{~g}$, vitamin B1 0,21 mg, dan antosianin (Indriyani et al, 2013).

Menurut Indriyani et al., (2013) mengonsumsi beras merah memiliki banyak manfaat bagi kesehatan yaitu dapat mencegah beberapa penyakit seperti penyakit hati (hepatitis), kanker usus, stroke, diabetes, dan mampu mengurangi pengaruh penuaan otak. Salah satu olahan sederhana dari beras merah yaitu pembuatan tepung. Tepung beras merupakan salah satu alternatif bahan dasar dari tepung komposit yang terdiri atas karbohidrat, lemak, protein, mineral, dan vitamin yang dapat dijadikan sebagai bahan baku industri lebih lanjut (Galung, 2017).

Kelor (Moringa oleifera) adalah salah satu jenis tanaman yang dapat tumbuh di daerah tropis dan subtropis pada semua jenis tanah seperti di Indonesia. Namun pemanfaatan daun kelor masih belum banyak diketahui karena pada umumnya hanya dikenal sebagai salah satu menu sayuran. Selain dikonsumsi dalam bentuk menu sayuran, daun kelor juga dapat diolah menjadi bentuk serbuk yang dapat digunakan sebagai bahan fortifikasi untuk mencukupi nutrisi pada berbagai produk pangan seperti olahan pudding, kue, nugget, biskuit, dan olahan lainnya (Aminah et al, 2015).

Daun kelor memiliki kandungan gizi antara lain protein, $\beta$-karoten, vitamin $C$, mineral terutama zat besi dan kalsium, bahkan dalam beberapa literatur dijelaskan bahwa daun kelor mempunyai kadar protein 3 kali dari protein telur, 25 kali zat besi dan 3 kali vitamin $C$ bayam, 12 kali kalsium serta 2 kali protein susu (Diantoro, 2015). Mengonsumsi daun kelor memiliki banyak manfaat bagi kesehatan misalnya menurunkan berat badan, mencegah penyakit jantung, mengatasi diabetes, menyehatkan mata, mengobati rematik bahkan dapat mengobati kanker (Isnan dan Nurhaedah, 2017).

Pembuatan rice crackers dengan penambahan tepung beras merah dan serbuk daun kelor diharapkan mampu menambah kualitas yang ada pada pangan tersebut sehingga dapat menjadi produk 
pangan fungsional. Pangan fungsional adalah pangan yang secara alamiah maupun yang telah melalui proses, mengandung satu atau lebih senyawa yang mempunyai fungsi-fungsi tertentu berdasarkan kajiankajian ilmiah yang bermanfaat bagi kesehatan.

\section{Tujuan Penelitian}

Penelitian ini bertujuan untuk mengetahui pengaruh penambahan tepung beras merah dan serbuk daun kelor terhadap kualitas rice crackers.

\section{Bahan dan Metode}

\section{Jenis Penelitian}

Jenis penelitian ini adalah penelitian kuantitatif dengan pendekatan eksperimen. Penelitian ini menggunakan rancangan acak lengkap (RAL) dengan 5 perlakuan yang terdiri dari perbandingan tepung beras merah dan serbuk daun kelor yaitu kontrol, 50:0 \%, 48:2 \%, 47,5:2,5\%, dan 47:3\% dengan 3 kali ulangan.

\section{Waktu dan Tempat Penelitian}

Penelitian ini dilaksanakan di Labolatorium Pendidikan Teknologi Pertanian Fakultas Teknik Universitas Negeri Makassar dan Labolatorium Kimia Makanan Ternak Fakultas Peternakan Universitas Hasanuddin Makassar yang dilaksanakan pada bulan Juni-Oktober 2018.

\section{Alat dan Bahan}

Peralatan yang digunakan dalam penelitian ini terdiri dari blender, sendok, mixer, baskom, oven, sendok, gelas, loyang, timbangan, cetakan kue, penggaris, spektrofotometer dan peralatan lain untuk analisis atau pengujian.

Bahan-bahan yang digunakan dalam penelitian ini yaitu tepung beras ketan Rose Brand, tepung beras merah, serbuk daun kelor, minyak sawit, gula, garam, baking powder, air, dan bahan lain yang digunakan untuk analisis kimia.

\section{Prosedur Penelitian}

\section{Pembuatan Tepung Beras Merah}

Proses pembuatan tepung beras merah dimulai dengan mencuci beras merah dengan air bersih, kemudian beras merah direndam selama 12 jam, setelah itu beras merah ditiriskan lalu dijemur. Setelah kering beras merah digiling menjadi tepung, kemudian beras merah diayak dengan menggunakan ayakan 80 mesh.

\section{Pembuatan Serbuk Daun Kelor}

Proses pembuatan serbuk daun kelor dimulai dengan memisahkan daun kelor dari tangkainya lalu disortasi dari daun kelor yang sudah kuning atau rusak. Daun kelor yang digunakan dalam proses pembuatan serbuk adalah daun yang sudah tua. Setelah itu daun kelor dicuci hingga bersih untuk menghilangkan kotoran kemudian ditiriskan, lalu daun kelor dikeringkan di dalam ruangan pengering (cahaya matahari) atau menggunakan mesin pengering pada suhu $60{ }^{\circ} \mathrm{C}$ selama 5 jam. Daun yang sudah kering dan dapat dijadikan tepung dicirikan dengan daunnya rapuh dan mudah dihancurkan, setelah itu daun kelor digiling hingga menjadi serbuk, serbuk daun kelor sebaiknya disimpan dalam wadah yang kedap udara dan terhindar dari panas dan kelembaban serta suhu dibawah $24{ }^{\circ} \mathrm{C}$.

\section{Pembuatan Rice crackers}

Proses pembuatan rice crakers dimulai dengan mencampurkan bahan (tepung ketan, tepung beras merah, serbuk daun kelor, garam, gula, dan baking powder) lalu diaduk hingga merata. Kemudian tambahkan minyak sawit lalu diaduk kembali. Setelah itu tambahkan air sambil diuleni dan adonan dikukus pada suhu 100 ${ }^{\circ} \mathrm{C}$ selama 2 menit. Kemudian adonan dipipihkan dan dicetak dengan ketebalan $0,1 \mathrm{~cm}$. Setelah itu adonan kembali dikukus pada suhu $100{ }^{\circ} \mathrm{C}$ selama 40 menit dan dinginkan selama 15 menit, Kemudian 
dipanggang pada suhu $180{ }^{\circ} \mathrm{C}$ selama 6 menit.

\section{Hasil Dan Pembahasan}

\section{Uji Organoleptik}

\section{Warna}

Warna merupakan sensori pertama yang dapat dilihat langsung oleh panelis dan pada umumnya penentuan mutu bahan makanan bergantung pada warna yang dimiliki. Menurut Ruchdiansyah et al., (2016), warna merupakan komponen utama dalam menentukan kualitas suatu bahan pangan. Hasil analisis terhadap warna rice crackers yang dihasilkan (Gambar 1) menunjukkan bahwa tingkat kesukaan panelis berkisar antara 3,36-3,75 yang berarti panelis agak menyukai rice crackers yang dihasilkan. Perlakuan $\mathrm{K}$ memiliki warna kuning kecoklatan, perlakuan A memiliki warna kemerahan yang disebabkan senyawa antosianin pada beras merah, dan perlakuan B sampai D memiliki warna merah kehijauan. Hal ini dikarenakan pada perlakuan B sampai D dilakukan penambahan tepung beras merah dan serbuk daun kelor.

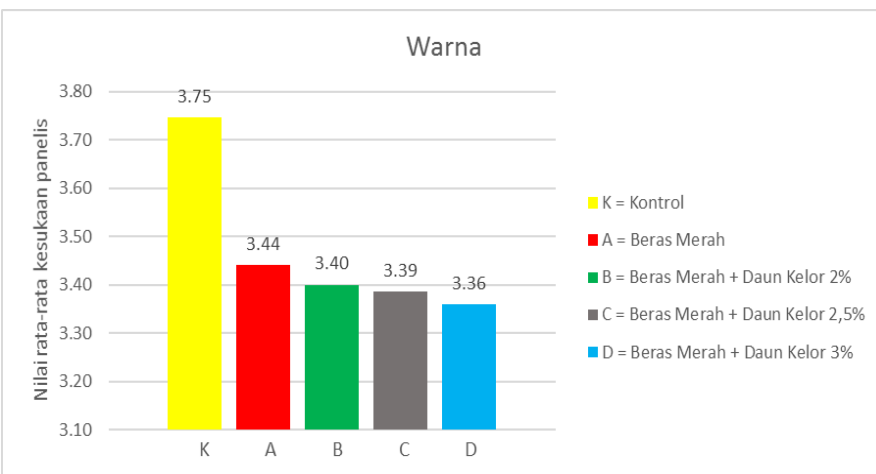

Gambar 1. Tingkat Kesukaan Panelis terhadap Warna

Hasil analisis sidik ragam terhadap warna rice crackers dengan penambahan tepung beras merah dan serbuk daun kelor, menunjukkan bahwa perlakuan memberikan pengaruh nyata dengan nilai $\mathrm{F}$ hitung (8.584) > F tabel 5\% (3.47805), sehingga dapat dilakukan uji lanjut. Berdasarkan hasil uji lanjut Duncan (DMRT) warna rice crackers yang dihasilkan, menunjukkan bahwa perlakuan konsentrasi penambahan tepung beras merah dan serbuk daun kelor memiliki perbedaan. Perlakuan A, B, C, dan D sama akan tetapi berbeda nyata dengan perlakuan $\mathrm{K}$ (kontrol).

Analisis kesukaan panelis terhadap warna rice crackers yang tertinggi adalah perlakuan K (kontrol) yang memiliki warna kuning kecokelatan. Hal ini dikarenakan pada saat pemanggangan terjadi reaksi maillard sehingga menghasilkan warna kuning kecokelatan. Sedangkan pada perlakuan A, B, C, dan D yaitu dengan penambahan tepung beras merah dan serbuk daun kelor menghasilkan warna merah kehijauan.

Menurut Wahyuni et al., (2017), reaksi pencoklatan dipengaruhi oleh pemanasan pada suhu tinggi seperti proses pengeringan, penggorengan, pemanggangan, dan pemasakan. Beras merah mengandung senyawa antosianin dan serbuk daun kelor mengandung senyawa klorofil sehingga mempengaruhi produk yang dihasilkan. Penambahan serbuk daun kelor pada proses pengolahan makanan akan memberikan warna kehijauan yang disebabkan oleh senyawa klorofil (Alkham, 2014).

\section{Tekstur}

Tekstur pada makanan merupakan salah satu sifat bahan atau produk yang dapat dirasakan melalui sentuhan kulit atau pencicipan. Menurut Susilawati et al., (2018) tekstur merupakan salah satu tolak 
ukur penilaian mutu suatu bahan pangan yang berhubungan dengan perabaan dan sentuhan. Hasil analisis terhadap tekstur rice crackers yang dihasilkan (Gambar 2) menunjukkan bahwa tingkat kesukaan panelis berkisar antara 3,08-3,65 yang berarti panelis agak menyukai rice crackers yang dihasilkan. Perlakuan $\mathrm{K}$ memiliki tekstur renyah sedangkan pada perlakuan A sampai D memiliki tekstur mulai dari renyah hingga agak keras.

Hasil analisis sidik ragam terhadap tekstur rice crackers dengan penambahan tepung beras merah dan serbuk daun kelor, menunjukkan bahwa perlakuan memberikan pengaruh nyata dengan nilai $\mathrm{F}$ hitung (14.118) > F tabel 5\% (3.47805), sehingga dapat dilakukan uji lanjut. Berdasarkan hasil uji lanjut Duncan (DMRT) tekstur rice crackers yang dihasilkan, menunjukkan bahwa perlakuan konsentrasi penambahan tepung beras merah dan serbuk daun kelor memiliki perbedaan. Perlakuan A, B, C, dan D sama akan tetapi berbeda nyata dengan perlakuan K (kontrol).

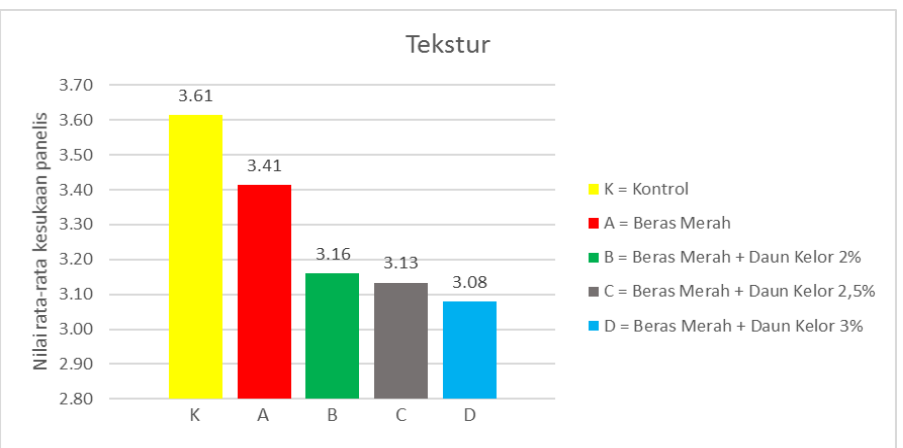

Gambar 2. Tingkat Kesukaan Panelis terhadap Tekstur

Analisis kesukaan panelis terhadap tekstur rice crackers yang tertinggi adalah perlakuan $\mathrm{K}$ (kontrol). Hal ini dikarenakan pada perlakuan kontrol memiliki tekstur yang renyah dan umumnya lebih disukai oleh panelis. Sedangkan pada perlakuan A, $\mathrm{B}, \mathrm{C}$, dan $\mathrm{D}$ yaitu dengan penambahan tepung beras merah dan serbuk daun kelor menghasilkan tekstur seperti berpasir dan keras.

Menurut Thoif (2014), semakin banyak tepung beras yang ditambahkan maka tekstur yang dihasilkan akan seperti berpasir. Hal ini disebabkan karena tidak terjadinya proses gelatinisasi yang sempurna pada saat proses pengolahan. Menurut Putri (2018), amilopektin berperan untuk meningkatkan kerenyahan sedangkan amilosa berperan untuk meningkatkan kekerasan produk. Kandungan amilosa pada beras ketan lebih rendah dibandingkan beras merah sehingga pada perlakuan kontrol memiliki tekstur yang lebih renyah dibandingkan perlakuan dengan penambahan tepung beras merah.
Menurut Nurlaila et al., (2016), kemampuan protein untuk menyerap dan menahan air mempunyai peranan penting dalam pembentukan tekstur suatu produk pangan.

\section{Rasa}

Rasa merupakan tingkat kesukaan yang dihasilkan dari indera perasa yang dapat dikategorikan menjadi 3 antara lain kurang enak, enak, dan sangat enak. Menurut Ruchdiansyah et al., (2016), penilaian rasa sulit dimengerti secara jelas dikarenakan selera setiap orang yang berbeda. Hasil analisis terhadap rasa rice crackers yang dihasilkan (Gambar 3) menunjukkan bahwa tingkat kesukaan panelis berkisar antara 3,36-3,75 yang berarti panelis agak menyukai rice crackers yang dihasilkan. Perlakuan $\mathrm{K}$ dan $\mathrm{A}$ memiliki rasa gurih sedangkan pada perlakuan B sampai D memiliki rasa gurih hingga sedikit pahit yang disebabkan oleh penambahan serbuk daun kelor yang memberikan rasa pahit. 


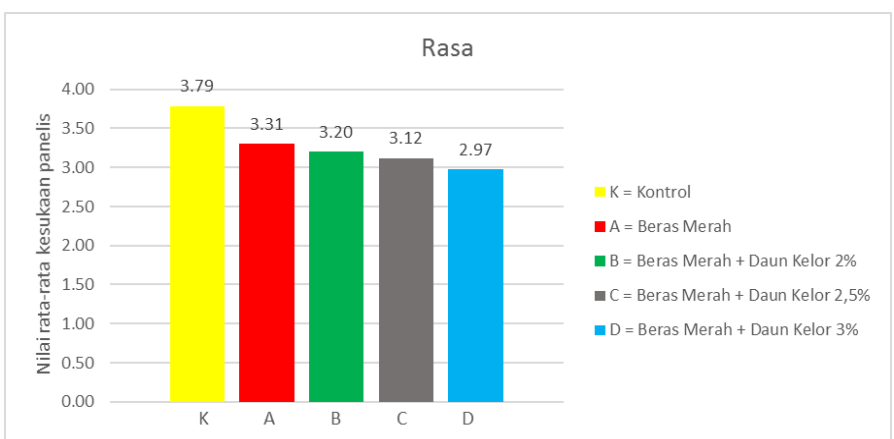

Gambar 3. Tingkat Kesukaan Panelis terhadap Rasa

Hasil analisis sidik ragam terhadap rasa rice crackers dengan penambahan tepung beras merah dan serbuk daun kelor, menunjukkan bahwa perlakuan memberikan pengaruh nyata dengan nilai $\mathrm{F}$ hitung (16.339) > F tabel 5\% (3.478), sehingga perlu dilakukan uji lanjut. Berdasarkan hasil uji lanjut Duncan (DMRT) rasa rice crackers yang dihasilkan, menunjukkan bahwa perlakuan konsentrasi penambahan tepung beras merah dan serbuk daun kelor memiliki perbedaan. Perlakuan A, B, C, dan D sama akan tetapi berbeda nyata dengan perlakuan $\mathrm{K}$ (kontrol).

Analisis kesukaan panelis terhadap rasa rice crackers yang tertinggi adalah perlakuan K (kontrol). Hal ini dikarenakan pada perlakuan kontrol memiliki rasa gurih dan umumnya lebih disukai oleh panelis. Sedangkan pada perlakuan A, B, C, dan D yaitu dengan penambahan tepung beras merah dan serbuk daun kelor menghasilkan rasa yang agak pahit.

Adanya rasa pahit yang ditimbulkan pada produk yang dihasilkan disebabkan oleh kandungan senyawa tanin pada daun kelor yang bersifat pahit (Isnan dan Nurhaedah, 2017). Menurut Alkham (2014), daun kelor mengandung tanin, gallic tanin, steroid dan triperpenoid, flavonoid, saponin, dan alkaloid. Sehingga semakin tinggi penambahan serbuk daun kelor maka semakin terasa pahit rice crackers yang dihasilkan.

\section{Aroma}

Aroma merupakan atribut organoleptik yang dapat dinilai melalui indera penciuman yang dapat menentukkan penerimaan produk. Menurut Ruchdiansyah et al., (2016), aroma merupakan sesuatu yang dapat diamati dengan indera pembau atau penciuman. Aroma dianggap sangat penting karena dapat menentukan dengan cepat diterima atau tidaknya suatu produk dan merupakan faktor yang sukar didefinisikan secara objektif (Nurlaila, 2016).

Hasil analisis terhadap aroma rice crackers yang dihasilkan (Gambar 4) menunjukkan bahwa tingkat kesukaan panelis berkisar antara 2,87-3,16 yang berarti panelis agak menyukai rice crackers yang dihasilkan. Pada perlakuan $\mathrm{K}$ menghasilkan aroma khas beras sedangkan pada perlakuan A sampai D menghasilkan aroma khas beras hingga aroma khas daun kelor. Hal ini dikarenakan pada perlakuan A sampai D dilakukan penambahan serbuk daun kelor sehingga mempengaruhi tingkat kesukaan panelis. 


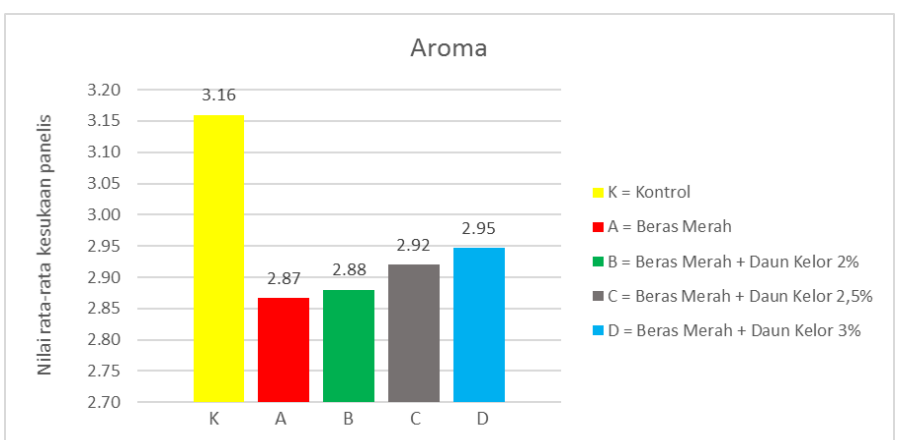

Gambar 4. Tingkat Kesukaan Panelis terhadap Aroma

Hasil analisis sidik ragam terhadap aroma rice crackers dengan penambahan tepung beras merah dan serbuk daun kelor, menunjukkan bahwa perlakuan memberikan pengaruh nyata dengan nilai $\mathrm{F}$ hitung (17.348) > F tabel 5\% (3.478), sehingga perlu dilakukan uji lanjut. Berdasarkan hasil uji lanjut Duncan (DMRT) pada aroma rice crackers yang dihasilkan menunjukkan bahwa perlakuan konsentrasi penambahan tepung beras merah dan serbuk daun kelor memiliki perbedaan. Perlakuan A, B, C, dan D sama akan tetapi berbeda nyata dengan perlakuan $\mathrm{K}$ (kontrol).

Analisis kesukaan panelis terhadap aroma rice crackers yang tertinggi adalah perlakuan K (kontrol). Hal ini dikarenakan pada perlakuan kontrol memiliki aroma beras dan umumnya lebih disukai oleh panelis. Sedangkan pada perlakuan A, B, C, dan $\mathrm{D}$ yaitu dengan penambahan tepung beras merah dan serbuk daun kelor menghasilkan aroma khas daun kelor.

Menurut Mayasari (2015), aroma pada produk pangan dapat dipengaruhi oleh bahan-bahan yang digunakan dan proses pengolahannya. Sehingga semakin banyak penambahan tepung beras merah dan serbuk daun kelor maka akan menghasilkan aroma khas beras dan daun kelor yang sangat tajam sehingga tingkat kesukaan terhadap aroma semakin menurun (Ruchdiansyah et al., 2016).

\section{Analisis Kimia}

\section{Kadar Air}

Kadar air adalah banyaknya air yang terkandung dalam bahan dan dinyatakan dalam persen. Air juga merupakan komponen utama yang dapat mempengaruhi penampakan, tekstur, dan cita rasa makanan. Menurut Ruchdiansyah et al., (2016), kadar air yang tinggi dapat mengakibatkan mudahnya mikroorganisme untuk berkembangbiak sehingga terjadi perubahan pada bahan pangan. Hasil analisis terhadap kandungan kadar air rice crackers yang dihasilkan (Gambar 5) menunjukkan bahwa rata-rata kandungan air yang terdapat pada rice crackers yang dihasilkan berkisar antara 1,91-3,01\%. Berdasarkan syarat mutu crackers (biskuit), kandungan kadar air pada rice crackers dengan penambahan tepung beras merah dan daun kelor memenuhi standar karena lebih rendah dari SNI (maks. 5).

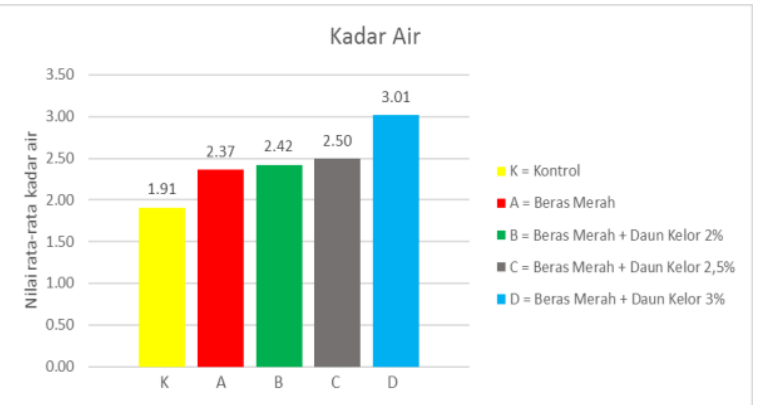

Gambar 5. Nilai Rata-rata Kadar Air Rice crackers 
Hasil analisis sidik ragam terhadap kadar air rice crackers dengan penambahan tepung beras merah dan serbuk daun kelor, menunjukkan bahwa perlakuan memberikan pengaruh nyata dengan nilai $\mathrm{F}$ hitung (60.501) > F tabel 5\% (3.4780497), sehingga dapat dilakukan uji lanjut. Berdasarkan hasil uji lanjut Duncan (DMRT) terhadap kadar air rice crackers yang dihasilkan, menunjukkan bahwa perlakuan konsentrasi penambahan tepung beras merah dan serbuk daun kelor memiliki perbedaan. Perlakuan A, B, dan C sama akan tetapi berbeda nyata dengan perlakuan K (kontrol) dan perlakuan D.

Terjadinya peningkatan kadar air dipengaruhi oleh bahan yang digunakan. Menurut Herawati et al., (2018), tepung beras merah mengandung kadar air sebanyak $11,3 \%$. Sedangkan tepung beras ketan memiliki kadar air sebesar 16,10\% (Mariana, 2010). Menurut Asfi et al., (2017), tingginya kadar air yang dihasilkan juga dipengaruhi oleh serat kasar yang memiliki kemampuan untuk mengikat air.

\section{Protein}

Protein adalah suatu zat makanan yang amat penting bagi tubuh, karena selain berfungsi sebagai sumber energi dalam tubuh juga berfungsi sebagai zat pembangun sel-sel dan jaringan tubuh. Menurut Ruchdiansyah et al., (2016), protein merupakan sumber asam-asam amino yang mengandung unsur-unsur $\mathrm{C}, \mathrm{H}$, $\mathrm{O}$, dan $\mathrm{N}$ yang tidak dimiliki oleh karbohidrat dan lemak.

Hasil analisis terhadap kandungan protein rice crackers yang dihasilkan (Gambar 6) menunjukkan bahwa rata-rata kandungan protein yang terdapat pada rice crackers yang dihasilkan berkisar antara $1,91-3,01 \%$. Berdasarkan syarat mutu crackers (biskuit), kandungan protein pada rice crackers dengan penambahan tepung beras merah dan daun kelor memenuhi standar karena lebih tinggi dari SNI (min. 5). Terjadinya peningkatan kandungan protein disebabkan tepung beras merah dan serbuk daun kelor memiliki kandungan protein yang cukup tinggi.

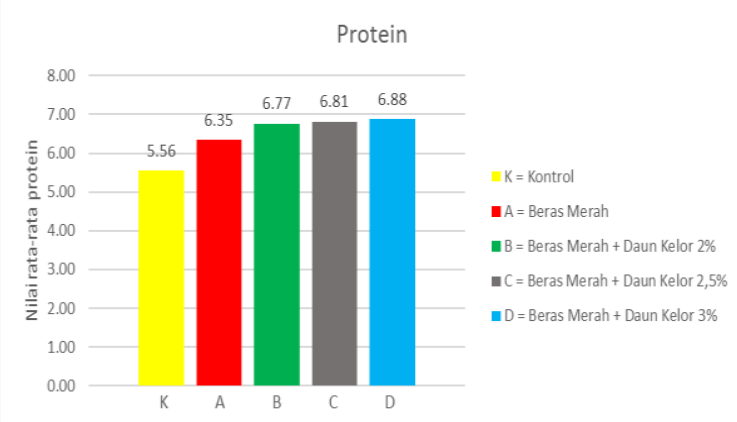

Gambar 6. Nilai Rata-rata Protein Rice crackers

Hasil analisis sidik ragam terhadap kandungan protein rice crackers dengan penambahan tepung beras merah dan serbuk daun kelor, menunjukkan bahwa perlakuan memberikan pengaruh nyata dengan nilai $\mathrm{F}$ hitung (52.436) > F tabel 5\% (3.478) dan 1\% (5.994338662), sehingga dapat dilakukan uji lanjut. Hasil uji lanjut Duncan (DMRT) terhadap kandungan protein rice crackers yang dihasilkan, menunjukkan bahwa perlakuan konsentrasi penambahan tepung beras merah dan serbuk daun kelor memiliki perbedaan.
Perlakuan B, C, dan D sama akan tetapi berbeda nyata dengan perlakuan $\mathrm{K}$ (kontrol) dan perlakuan A.

Menurut Nuryani (2013), beras merah mengandung protein sebesar 4,88 g. Sedangkan serbuk daun kelor memiliki kandungan protein sebesar 27,1 g (Isnan dan Nurhaedah, 2017). Sehingga semakin banyak penambahan serbuk daun kelor maka kandungan protein yang dihasilkan akan mengalami peningkatan. 


\section{Karbohidrat}

Karbohidrat adalah sumber energi bagi tubuh dan mempunyai peranan penting dalam menentukan karakteristik bahan makanan seperti rasa, warna, dan tekstur. Menurut Mariana (2010), karbohidrat mempunyai peranan penting dalam menentukan karakteristik bahan makanan seperti rasa, warna, dan tekstur. Komponen karbohidrat yang banyak terdapat pada produk pangan adalah pati, pektin, dan selulosa.
Hasil analisis terhadap kandungan protein rice crackers yang dihasilkan (Gambar 7) menunjukkan bahwa rata-rata kandungan karbohidrat yang terdapat pada rice crackers yang dihasilkan berkisar antara 79,26-85,13\%. Berdasarkan syarat mutu crackers (biskuit), kandungan karbohidrat pada rice crackers dengan penambahan tepung beras merah dan daun kelor memenuhi standar karena lebih tinggi dari SNI (min. 70).

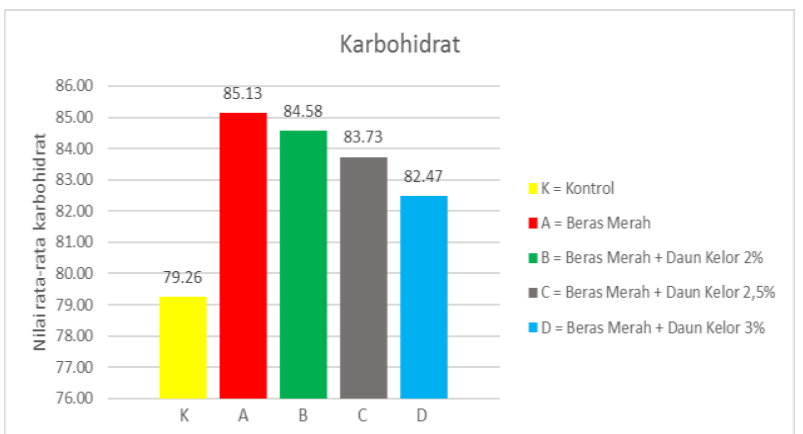

Gambar 7. Nilai Rata-rata Karbohidrat Rice crackers

Hasil analisis sidik ragam terhadap karbohidrat rice crackers dengan penambahan tepung beras merah dan serbuk daun kelor, menunjukkan bahwa perlakuan memberikan pengaruh nyata dengan nilai $\mathrm{F}$ hitung (17.085) $>\mathrm{F}$ tabel $5 \%$ (3.478), sehingga dapat dilakukan uji lanjut. Berdasarkan hasil uji lanjut Duncan (DMRT) kandungan karbohidrat rice crackers yang dihasilkan, menunjukkan bahwa perlakuan konsentrasi penambahan tepung beras merah dan serbuk daun kelor memiliki perbedaan. Perlakuan A, B, dan C sama akan tetapi berbeda nyata dengan perlakuan K (kontrol) dan perlakuan D.

Menurut Nuryani (2013), beras merah memiliki kandungan karbohidrat sebesar 49,7 g. Sedangkan serbuk daun kelor memiliki kandungan karbohidrat sebesar
38,2 g (Isnan dan Nurhaedah, 2017). Sehingga semakin banyak penambahan tepung beras merah maka kandungan karbohidrat yang dihasilkan juga akan ikut meningkat.

\section{Lemak}

Lemak adalah salah satu komponen zat gizi makro yang dapat menentukan mutu suatu produk. Lemak merupakan faktor penting yang harus diperhatikan dalam makanan karena dapat menyebabkan perubahan sifat pada makanan tersebut (ketengikan). Menurut Mariana (2010), lemak dapat memperbaiki struktur fisik pada pangan seperti pengembangan, kelembutan tekstur, dan aroma. 


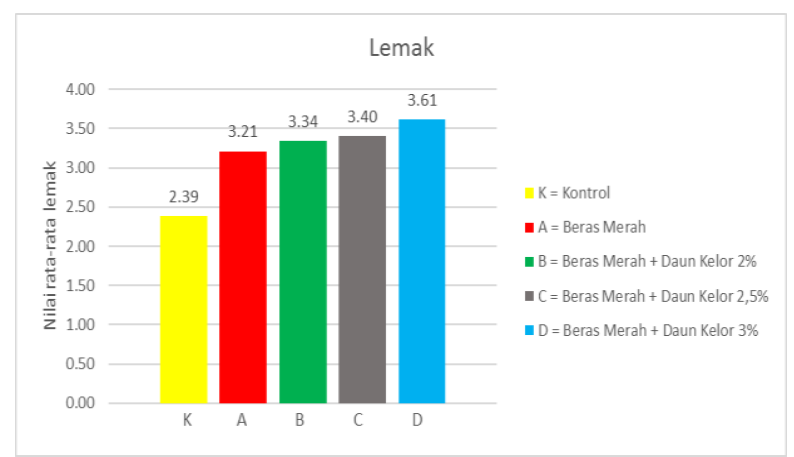

Gambar 8. Nilai Rata-rata Lemak Rice crackers

Hasil analisis terhadap kandungan lemak rice crackers yang dihasilkan (Gambar 8) menunjukkan bahwa rata-rata kandungan lemak yang terdapat pada rice crackers yang dihasilkan berkisar antara 2,39-3,61\%. Berdasarkan syarat mutu crackers (biskuit), kandungan lemak pada rice crackers dengan penambahan tepung beras merah dan daun kelor tidak memenuhi standar karena lebih rendah dari SNI (min. 9,5) yang disebabkan rendahnya kandungan lemak pada bahan yang digunakan.

Hasil analisis sidik ragam terhadap lemak rice crackers dengan penambahan tepung beras merah dan serbuk daun kelor, menunjukkan bahwa perlakuan memberikan pengaruh nyata dengan nilai $\mathrm{F}$ hitung (21.069) > F tabel 5\% (3.478), sehingga dapat dilakukan uji lanjut. Berdasarkan hasil uji lanjut Duncan (DMRT) lemak rice crackers yang dihasilkan, menunjukkan bahwa perlakuan konsentrasi penambahan tepung beras merah dan serbuk daun kelor memiliki perbedaan. Perlakuan B, C, dan D sama akan tetapi berbeda nyata dengan perlakuan $\mathrm{K}$ (kontrol) dan perlakuan A.

Menurut Nuryani (2013), beras merah memiliki kandungan lemak sebesar $1,17 \mathrm{~g}$ dan daun kelor sebesar 2,3 g. Sehingga semakin banyak penambahan serbuk daun kelor maka kandungan lemak pada rice crackers yang dihasilkan akan meningkat. Menurut Ismanto dan Fauziah (2016), lemak berfungsi untuk memperbaiki tekstur dan citarasa dari bahan pangan.

\section{Serat Kasar}

Serat kasar merupakan salah satu penilaian yang penting dalam menentukan kualitas bahan makanan karena angka ini merupakan indeks dan menentukan nilai gizi bahan makanan tersebut. Menurut Kustiani (2013), serat merupakan bagian yang tidak dapat dihidrolisis oleh bahanbahan kimia (asam sulfat dan natrium hidroksida).

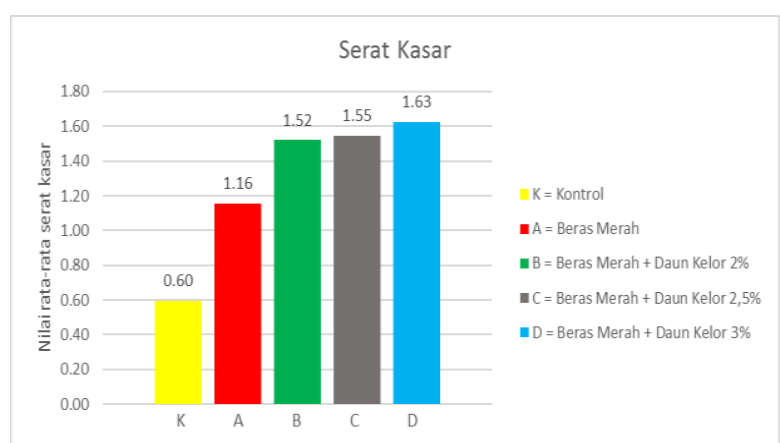

Gambar 9. Nilai Rata-rata Serat Kasar Rice Crackers 
Hasil analisis terhadap kandungan serat kasar rice crackers yang dihasilkan (Gambar 9) menunjukkan bahwa rata-rata kandungan serat kasar berkisar antara 0,601,63\%. Berdasarkan syarat mutu crackers (biskuit), kandungan serat kasar pada rice crackers dengan penambahan tepung beras merah dan daun kelor memenuhi standar karena lebih tinggi dari SNI (min. 0,5).

Hasil analisis sidik ragam terhadap serat kasar rice crackers dengan penambahan tepung beras merah dan serbuk daun kelor, menunjukkan bahwa perlakuan memberikan pengaruh nyata dengan nilai $\mathrm{F}$ hitung $(179.842)>\mathrm{F}$ tabel 5\% (3.478), sehingga dapat dilakukan uji lanjut. Berdasarkan hasil uji lanjut Duncan (DMRT) serat kasar rice crackers yang dihasilkan, menunjukkan bahwa perlakuan konsentrasi penambahan tepung beras merah dan serbuk daun kelor memiliki perbedaan. Perlakuan B, C, dan D sama akan tetapi berbeda nyata dengan perlakuan K (kontrol) dan perlakuan A.

Beras merah dan daun kelor memiliki kandungan serat yang cukup tinggi sehingga semakin banyak penambahan tepung beras merah dan serbuk daun kelor maka kandungan serat kasar juga akan meningkat. Menurut Nuryani (2013), beras merah memiliki kandungan serat sebesar 3,32 g. Sedangkan serbuk daun kelor mengandung serat sebesar 12,5 $\mathrm{g}$ (Isnan dan Nurhaedah, 2017).

Menurut Andrasari et al., (2019), serat memiliki kemampuan untuk mengikat air secara cepat dalam jumlah yang banyak. Sehingga semakin banyak penambahan tepung beras merah atau serbuk daun kelor maka kandungan serat yang dihasilkan juga akan ikut meningkat.

\section{Fosfor}

Fosfor merupakan mineral kedua yang terbanyak di dalam tubuh. Fosfor berfungsi untuk mengubah makanan menjadi energi yang penting untuk memelihara laju metabolisme tetap berlangsung. Hasil analisis terhadap kandungan fosfor rice crackers yang dihasilkan (Gambar 10) menunjukkan bahwa rata-rata kandungan fosfor berkisar antara 0,11-0,22\%.

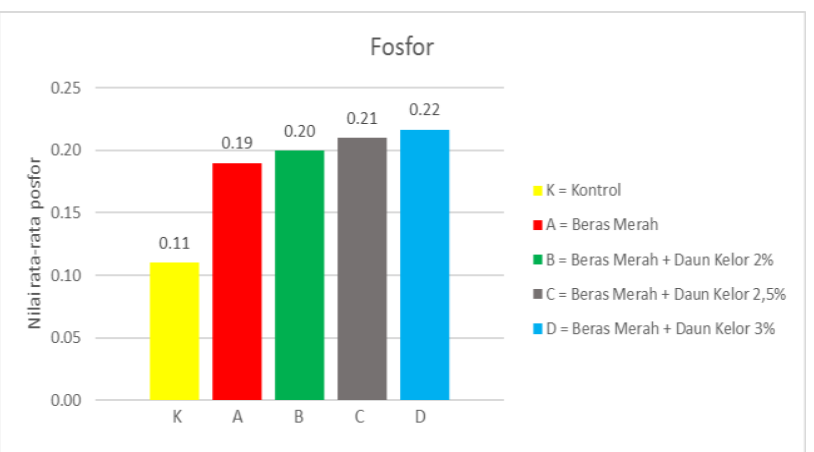

Gambar 10. Nilai Rata-rata Fosfor Rice Crackers

Hasil analisis sidik ragam terhadap protein rice crackers dengan penambahan tepung beras merah dan serbuk daun kelor, menunjukkan bahwa perlakuan memberikan pengaruh nyata dengan nilai $\mathrm{F}$ hitung (35.974) > F tabel 5\% (3.478), sehingga dapat dilakukan uji lanjut. Berdasarkan hasil uji lanjut Duncan (DMRT) kandungan fosfor rice crackers yang dihasilkan, menunjukkan bahwa perlakuan konsentrasi penambahan tepung beras merah dan serbuk daun kelor memiliki perbedaan. Perlakuan B, C, dan D sama akan tetapi berbeda nyata dengan perlakuan K (kontrol) dan perlakuan A.

Terjadinya peningkatan kandungan fosfor dipengaruhi oleh kandungan fosfor yang terdapat pada beras merah dan daun kelor yaitu sebanyak $204 \mathrm{mg}$ sehingga semakin tinggi penambahan tepung beras merah atau serbuk daun kelor maka kandungan fosfor juga akan meningkat 
(Isnan dan Nurhaedah, 2017). Menurut Astuti dan Djarot (2015), angka kecukupan fosfor rata-rata dalam sehari adalah bayi (200-250 mg), anak-anak (250-400 mg), remaja dan dewasa (400-500 mg).

\section{Simpulan}

Berdasarkan dari data hasil penelitian, maka dapat disimpulkan bahwa penambahan tepung beras merah dan serbuk daun kelor berpengaruh terhadap kualitas rice crackers yang meliputi organoleptik (warna, tekstur, rasa, dan aroma, kadar air, protein, karbohidrat, lemak, serat kasar, dan fosfor). Pada pembuatan rice crackers dengan penambahan tepung beras merah dan serbuk daun kelor dihasilkan perlakuan terbaik yang berdasarkan analisis kimia dan tingkat kesukaan panelis pada perlakuan B dengan perbandingan $48 \%$ tepung beras merah dan $2 \%$ serbuk daun kelor sebagai perlakuan terbaik dengan kadar air 2,42\%, protein $6,77 \%$, karbohidrat $84,58 \%$, lemak $3,34 \%$, serat kasar $1,52 \%$, dan fosfor $0,20 \%$.

\section{Daftar Pustaka}

Andrasari E., Lahming, \& Ratnawaty F. 2019. Pengaruh Penambahan Tepung Rebung (Gigantochloa apus) terhadap Mutu Mie Basah. Jurnal Pendidikan Teknologi Pertanian. 5 (1): 24-29.

Alkham F.F. 2014. Uji Kadar Protein dan Organoleptik Biskuit Tepung Terigu dan Tepung Daun Kelor (Moringa oleifera) dengan Penambahan Jamur Tiram (Pleurotus ostreatus). Naskah Publikasi. Surakarta: Universitas Muhammadiyah Surakarta.

Aminah S., Tezar R., \& Muflihani Y. 2015. Kandungan Nutrisi dan Sifat Fungsional Tanaman Kelor (Moringa oleifera). Buletin Pertanian Perkotaan. 5 (2): 35-44.

Asfi W.M., Noviar H., \& Yelmira. 2017. Pemanfaatan Tepung Kacang Merah dan Pati Sagu pada Pembuatan Crackers. Jom Faperta UR. 4 (1): 1-12

Astuti R.D., \& Djarot S. 2015. Penentuan Kadar Mineral Seng (Zn) dan Fosfor (P) dalam Nugget Ikan Gabus (Channa striata) Rumput Laut Merah (Eucheuma spinosum). Jurnal Sains dan Seni. 4 (2): 80-85

Badan Standardisasi Nasional. 2011. Biskuit. SNI 01-2973 :2011. Badan Standardisasi Nasional: Jakarta.

Diantoro A. 2015. Pengaruh Penambahan Ekstrak Daun Kelor (Moringa oleifera 1.) terhadap Kualitas Yoghurt. Jurnal Teknologi Pangan. 6 (2):59-66.

Galung F.S. 2017. Karakterisasi dan Pengaruh Berbagai Perlakuan terhadap Produksi Tepung Beras Merah (Oryza nivara) Instan. Program Studi Agribisnis Fakultas Pertanian. Universitas Cokroaminoto Palopo.

Herawati B.R., Nanik S., \& Yannie A.W. 2018. Cookies Tepung Beras Merah (Oryza nivara) Mocaf (Modified cassava flour) dengan Penambahan Bubuk Kayu Manis (Cinnamomun burmanni). Jurnal Jitipari. 5: 33-40

Indriyani F., Nurhidajah, \& Agus S. 2013. Karakteristik Fisik, Kimia dan Sifat Organoleptik Tepung Beras Merah Berdasarkan Variasi Lama Pengeringan. Jurnal Pangan dan Gizi. 04 (08).

Ismanto S.D., \& Fauziah A. 2016. Pengaruh Penambahan Daun Cincau Hijau (Premma oblongifolia, $M$ ) terhadap Aktivitas Antioksidan dan Karakteristik Crackers yang dihasilkan. Artikel. disajikan pada Seminar Nasional Perhimpunan Ahli Teknologi Pangan Indonesia (PATPI) 2016. Makassar. 18-20 Agustus 2016. 
Isnan W., \& Nurhaedah M. 2017. Ragam Manfaat Tanaman Kelor (Moringa oleifera lamk.) bagi Masyarakat. Info Teknis EBONI. 14 (1): 63-75.

Kustiani AL. 2013. Pengembangan Crackers Sumber Protein dan Mineral dengan Penambahan Tepung Daun Kelor (Moringa oleifera) dan Tepung Badan-Kepala Ikan Lele Dumbo (Clarias gariepinus). Skripsi. Bogor: Departemen Gizi Masyarakat Fakultas Ekologi Manusia Institut Pertanian Bogor.

Mariana E. 2010. Pembuatan Crackers Jagung dan Pendugaan Umur Simpannya dengan Pendekatan Kadar Air Kritis. Skripsi. Fakultas Teknologi Pertanian. Institut Pertanian Bogor.

Mayasari R. 2015. Pemanfaatan Tepung Kacang Merah dan Pati Sagu pada Pembuatan Crackers. Skripsi. Universitas Pasundan Bandung.

Nurlaila, Andi S., \& Amiruddin. 2016. Pengembangan Produk Sosis Fungsional Berbahan Dasar Ikan Tenggiri (Scomberomorus sp.) dan Tepung Daun Kelor (Moringa oleifera l.). Jurnal Pendidikan Teknologi Pertanian. 2: 105-113.

Nuryani. 2013. Potensi Subtitusi Beras Putih dengan Beras Merah sebagai Makanan Pokok untuk Perlindungan Diabetes Melitus. Media Gizi Masyarakat Indonesia. 3 (3): 157-168.

Putri R.D. 2018. Kadar Amilosa, Tingkat Kekerasan, dan Sifat Sensori Stick dengan Substitusi Tepung Gadung (Dioscorea hipsida dennst). Jurnal. Program Studi Teknologi Pangan. Fakultas Ilmu Keperawatan dan Kesehatan. Universitas Muhammadiyah Semarang.

Ruchdiansyah D., Novidahlia, \& Amalia. 2016. Formulasi Kerupuk dengan
Penambahan Daun Kelor (Moringa oleifera). Jurnal Pertanian. 7 (2): 5165.

Susilawati B.S., Husain S, \& Ratnawaty F. 2018. Pengaruh Modifikasi Tepung Jagung Pragelatinisasi terhadap Kualitas Cookies. Jurnal Pendidikan Teknologi Pertanian. 4: 27-48.

Thoif R.A. 2014. Formulasi Substitusi Tepung Beras Merah (Oryza nivara) dan Ketan Hitam (Oryza sativa glutinosa) dalam Pembuatan Cookies Fungsional. Skripsi. Institut Pertanian Bogor.

Wahyuni S.M., Mohammad W., \& Kadirman. 2017. Pemanfaatan Tepung Ubi Jalar (Ipomea btatas 1) berbagai Varietas sebagai Bahan Baku Pembuatan Kue Bolu Kukus. Jurnal Pendidikan Teknologi Pertanian. 3: 60-71. 